\title{
PAPP-A, IGFBP-4 and IGF-II are secreted by human adipose tissue cultures in a depot-specific manner
}

\author{
Mette Faurholdt Gude', Rikke Hjortebjerg ${ }^{1,2}$, Claus Oxvig33, Anne Anker Thyø ${ }^{4}$, \\ Nils Erik Magnusson ${ }^{1}$, Mette Bjerre', Steen Bønløkke Pedersen ${ }^{1,5}$ and Jan Frystyk ${ }^{1,5}$
}

${ }^{1}$ Medical Research Laboratory, Department of Clinical Medicine, Faculty of Health, Aarhus University, Aarhus C, Denmark, ${ }^{2}$ Danish Diabetes Academy, Odense, Denmark, ${ }^{3}$ Department of Molecular Biology and Genetics, Faculty of Science and Technology, Aarhus University, Aarhus C, Denmark, ${ }^{4}$ Departments of Abdominal Surgery, and ${ }^{5}$ Endocrinology and Internal Medicine, Aarhus University Hospital, Aarhus C, Denmark

Correspondence should be addressed to J Frystyk Email

Frystyk@clin.au.dk

\begin{abstract}
Objective: Adipose tissue secretes pregnancy-associated plasma protein-A (PAPP-A), which may increase local IGF action through cleavage of IGF-binding protein-4 (IGFBP-4). We tested whether this mechanism was operational in human visceral and subcutaneous adipose tissue (i.e. VAT and SAT).

Design: Explants of VAT and SAT from 26 obese subjects (hereof 17 women, BMI $39.5(37.2 ; 42.8) \mathrm{kg} / \mathrm{m}^{2}$ (median (25\%; $75 \%$ confidence interval) and SAT from eight lean, age-matched women (BMI $\left.23.6(22.4 ; 24.9) \mathrm{kg} / \mathrm{m}^{2}\right)$ were incubated with or without $\mathrm{GH}(100 \mu \mathrm{g} / \mathrm{L})$ and the media were harvested.

Methods: Media were assessed for concentrations of PAPP-A, intact and PAPP-A-cleaved IGFBP-4, IGF-I and IGF-II, and IGF-I receptor (IGF-IR) activation by bioassay.

Results: In obese subjects, VAT media contained higher concentrations than SAT of PAPP-A (4.4-fold) and both PAPPA-generated IGFBP-4 fragments (C-terminal: 3.3 -fold, N-terminal: 1.5-fold) (all $P<0.0005$ ). Intact IGFBP-4 levels were similar in SAT and VAT. VAT media contained elevated IGF-II (1.4-fold; $P<0.005)$, but similar IGF-I concentrations compared with SAT. Still, VAT media contained a 1.8 -fold increased ability to stimulate the IGF-IR $(P<0.005)$. IGF-I protein concentration and IGF-IR activation increased more in VAT media than SAT media following GH stimulation (both $P<0.05$ ). At baseline, SAT media protein levels from lean and obese women were similar, with the exception of PAPP-A being 1.8 -fold elevated in VAT media $(P<0.05)$. GH induced a similar increase in IGF-I media levels in SAT from obese and lean women.

Conclusion: Human adipose tissue cultures secrete enzymatically active PAPP-A, IGFBP-4 and IGF-II in a depot-specific manner, suggesting differential regulation of IGF activity. Further, IGF-II appears to be more prominent than IGF-I. Finally, VAT appears more GH responsive than SAT.
\end{abstract}

\section{Introduction}

Adipose tissue synthesizes proteins belonging to the insulin-like growth factor (IGF) system. This includes the IGF-I receptor (IGF-IR), its two ligands, IGF-I and IGF-II, and many of the IGF-binding proteins (IGFBPs)
$(1,2,3)$. The role of the IGF system in adipose tissue remains to be defined, but the expression and secretion of IGF-I appear to be important for adipocyte homeostasis. In vitro, IGF-I stimulates adipocyte growth and lipogenesis
() 2016 European Society of Endocrinology Printed in Great Britain
Published by Bioscientifica Ltd. 
(4) as well as the differentiation of pre-adipocytes into mature adipocytes, and IGF-I also controls anti-apoptotic signaling $(5,6,7,8)$.

The vast majority of the IGFs are complexed to IGFBPs, which block the growth factors from activating their primary target, the IGF-IR (9). Accordingly, to become receptor accessible the IGFs need to be liberated. This is achieved by enzymatic cleavage of the IGFBPs, causing release of bound IGF. Pregnancy-associated plasma protein-A (PAPP-A) is one of the most wellcharacterized IGFBP-degrading enzymes. The primary substrate for PAPP-A is IGFBP-4, which is cleaved in an IGF-dependent manner, and by this mechanism PAPP-A has been demonstrated to control growth, visceral fat accumulation and longevity in experimental animal models $(10,11,12)$.

Adipose tissue from different regions is inherently distinct in regard to expression and secretion of proand anti-inflammatory proteins $(13,14)$. The regional differences may explain that accumulation of visceral adipose tissue (VAT) associates more strongly with an unfavorable metabolic risk profile than does subcutaneous adipose tissue (SAT) (15). Also PAPP-A, which holds proatherosclerotic properties (11), appears to be secreted in a site-specific manner. Studies in experimental animals have demonstrated that PAPP-A is highly expressed in and secreted from pre-adipocytes of visceral origin compared with subcutaneous pre-adipocytes, and the expression and secretion of IGFBP-4 follow the same regional distribution $(10,16,17,18)$. At present, human data are scanty and it remains unknown whether the site-specific secretion of PAPP-A and IGFBP-4 translates into regional differences in local IGF action.

Insulin stimulates the hepatic growth hormone (GH) sensitivity by increasing the GH receptor (GHR) synthesis (19). This explains why obese subjects, despite a reduced GH secretion (20), are able to maintain serum IGF-I levels within the normal range $(21,22,23$, $24)$, and it also explains why obese subjects respond with a higher increase in serum IGF-I following GH administration than lean subjects (25). Whether obesity also augments the sensitivity to $\mathrm{GH}$ in human adipose tissue remains unknown.

This study aimed to compare the expression and secretion of components of the IGF system in media from cultures of SAT and VAT from obese subjects, focusing on media levels of PAPP-A, intact IGFBP-4 and PAPP-Agenerated IGFBP-4 fragments and their impact on IGF bioactivity. Furthermore, by stimulating SAT with GH in vitro, we tested the hypothesis that $\mathrm{GH}$ was able to induce a higher IGF-I production in adipose tissue from obese than lean women.

\section{Subjects and methods}

\section{Study participants}

VAT and SAT were collected peri-operatively during elective bariatric surgery from 26 obese subjects (age 38.0 (33.5; 43.5) (median (25\%; 75\% confidence interval)); BMI 39.5 $\left.(37.2 ; 42.8) \mathrm{kg} / \mathrm{m}^{2}\right)$, with no differences in BMI and age between women $(n=17$, age $38.0(29.0 ; 42.0)$ years, BMI $\left.40.1(35.4 ; 44.7) \mathrm{kg} / \mathrm{m}^{2}\right)$ and men $(n=9$, age $40.0(35.5$; $46.0)$ years, BMI $\left.39.3(38.2 ; 41.8) \mathrm{kg} / \mathrm{m}^{2}\right)$. SAT was collected from eight lean women (age 40.0 (30.0; 52.3) years, BMI $\left.23.6(22.4 ; 24.9) \mathrm{kg} / \mathrm{m}^{2}\right)$, whose age was matched with that of the obese women. The latter tissue samples originated from cosmetic liposuctions performed on the abdomen and/or the hips.

All lean subjects were healthy and took no medication influencing adipose tissue metabolism. Among obese subjects some received anti-hypertensives $(n=7)$, oral anti-diabetics $(n=5)$, anti-psychotics $(n=2)$, proton-pump inhibitors $(n=4)$, thyroxine $(n=4)$, anti-arrhythmics $(n=3)$, anti-estrogen $(n=1)$ or anti-thrombotics $(n=1)$, or were treated with medications for asthma $(n=1)$, osteoporosis $(n=1)$ or depression $(n=6)$. The project was approved by the local Ethical Committee and performed in accordance with the Helsinki Declaration.

\section{Adipose tissue culturing}

Immediately after collection, adipose tissue fragments were rinsed in sterile saline. SAT from lean women was incubated in fragments of $500 \mathrm{mg}$, floating freely in $5 \mathrm{~mL}$ incubation medium (consisting of Medium 199 (Sigma) supplemented with 25 mM HEPES, pH 7.4 and 1\% human serum albumin, $1 \mathrm{nM}$ insulin, antipain and leupeptin (each $20 \mathrm{~mL} / 100 \mathrm{~mL}$ medium) and penicillin $(100 \mathrm{IU} / \mathrm{mL})$ and streptomycin $(100 \mathrm{IU} / \mathrm{mL})\left(\right.$ each $1 \mathrm{~mL} / 100 \mathrm{~mL}$ medium)) at $37^{\circ} \mathrm{C}, 5 \% \mathrm{CO}_{2}$. Due to practical circumstances, the SAT and VAT fragments obtained during bariatric surgery only resulted in $200 \mathrm{mg}$ tissue fragments. These fragments were incubated in $2 \mathrm{~mL}$ incubation medium and consequently, the ratio between tissue and medium was similar for all fragments. After an equilibration period of $24 \mathrm{~h}$, tissues were incubated for $48 \mathrm{~h}$ at $37^{\circ} \mathrm{C}$ before harvest of cell media. SAT from lean women was incubated with various concentrations of GH (0 (i.e. baseline), 1, 10 and $100 \mu \mathrm{g} / \mathrm{L}$; Novo Nordisk A/S), whereas tissue samples from obese men and women were incubated 
without GH (baseline) and with GH $(100 \mu \mathrm{g} / \mathrm{L})$. After harvest, the media were frozen at $-20^{\circ} \mathrm{C}$ for later analysis of proteins, whereas tissue fragments were frozen in liquid nitrogen and kept at $-80^{\circ} \mathrm{C}$ for mRNA extraction.

\section{Bioactive IGF by kinase receptor activation assay (KIRA)}

The ability of IGFs present in cell media to stimulate the IGF-IR in vitro (i.e. IGF bioactivity) was measured by an in-house kinase receptor activation (KIRA) assay (26) with modifications (27). Media were diluted 1:2 before assay and all samples from the same patient were measured in the same assay. IGF-IR phosphorylation was compared with that of a serial dilution of recombinant human IGF-I (WHO 02/254; the National Institute for Biological Standards and Control (NIBSC), Potters Bar, Hertfordshire, UK). Samples with readings below detection limit (zero calibrator (NSB) plus 3 s.D. of the NSB signal) were given the concentration of zero. As the IGF-IR may be stimulated by IGF-I as well as IGF-II, the output of the assay has been designated 'bioactive IGF'.

\section{IGF-immunoassays}

Media concentrations of total, immunoreactive IGF-I were measured by in-house time-resolved immunofluorometric assay (TR-IFMA) following sample acidification and IGF-II blockage of IGFBPs as previously outlined (3) with modifications (28). Media were acidified to $\mathrm{pH}<3$ by a $1: 10$ dilution in acetic acid $(200 \mathrm{mM}, 0.5 \mathrm{~g} / \mathrm{L}$ HSA, $9 \mathrm{~g} / \mathrm{L} \mathrm{NaCl}$ and $5 \mathrm{~mL} / \mathrm{L}$ Tween 20) containing an excess of IGF-II $(200 \mu \mathrm{g} / \mathrm{L})$, and incubated for $2 \mathrm{~h}$ at $5^{\circ} \mathrm{C}$. The samples $(100 \mu \mathrm{L})$ were added directly to a 96-well microtiter plate, which before use had been coated with IGF-I antibody (MAb41, generously provided by Novo Nordisk A/S), blocked $\left(10 \mathrm{~mL} / \mathrm{L}\right.$ Tween $20,0.5 \mathrm{~g} / \mathrm{L} \mathrm{NaN}_{3}$ in $40 \mathrm{mM}$ PBS) and added $100 \mu \mathrm{L}$ Tris buffer $(400 \mathrm{mM}$, $\mathrm{pH}$ 8.5: $17.68 \mathrm{~g} / \mathrm{L}$ Tris-HCl, $34.88 \mathrm{~g} / \mathrm{L}$ Tris-base, $2.5 \mu \mathrm{M}$ EDTA, $2 \mathrm{~mL} / \mathrm{L}$ Tween $20,9 \mathrm{~g} / \mathrm{L} \mathrm{NaCl}$ and $1 \mathrm{~g} / \mathrm{L}$ HSA), which neutralized the acetic acid. After overnight incubation at $5^{\circ} \mathrm{C}$, the wells were washed $(50 \mathrm{mM}$ Tris- $\mathrm{HCl} \mathrm{pH} 8.0$ with $9 \mathrm{~g} / \mathrm{L} \mathrm{NaCl}, 5 \mathrm{~mL} / \mathrm{L}$ Tween 20 and $0.5 \mathrm{~g} / \mathrm{L} \mathrm{NaN}_{3}$ ) and $200 \mu \mathrm{L}$ of biotinylated IGF-I antibody (catalog \# I-8773, Sigma) containing europium-labeled streptavidin (1:1000; Perkin Elmer Life Science) were added to the wells. After incubation at room temperature for $2 \mathrm{~h}$, the wells were washed six times, enhancement solution (Perkin Elmer Life Science) was added to the wells and read using time-resolved immunofluorometry. A serial dilution of rhIGF-I (WHO 02/254) served as calibrator and was treated as cell media. All samples were assayed in duplicates.

Cell media levels of immunoreactive, total IGF-II were assayed in a similar manner. However, IGFBPs were blocked with $200 \mu \mathrm{g} / \mathrm{L}$ IGF-I and different antibodies were used for coating (clone S1F2, catalog \# 05-166, Merck Millipore) and detection (polyclonal antibody \# I-7276, Sigma, tagged with europium), and rhIGF-II (WHO 96/538, obtained from NIBSC) served as calibrator. Otherwise, the procedures were as described for IGF-I.

\section{IGFBP-4}

We originally assessed IGFBP-4 by a commercial assay, which had been validated for measurements in cell culture media (catalog \# DY804, Bio-Techne, Abingdon, UK), whereas its ability to recognize IGFBP-4 fragments generated by PAPP-A had not been explored. However, after having finalized all tissue incubations, we had the opportunity to establish three novel in-house IGFBP-4 assays that specifically targeted intact IGFBP-4, the PAPPA-generated C-terminal (CT) IGFBP-4 fragment and the PAPP-A-generated N-terminal (NT) IGFBP-4 fragment respectively. The three assays were based on antibodies and calibrators generously donated by HyTest Ltd. (Turku, Finland) and they have recently been described in detail (29). In brief, culture media levels of IGFBP-4, CT-IGFBP-4 and NT-IGFBP-4 were measured in duplicate using TR-IFMAs based on monoclonal antibodies and recombinant human calibrators generously provided by HyTest Ltd. In each fragment assay, one of the antibodies specifically recognizes the proteolytic neo-epitope generated upon degradation of IGFBP-4 by PAPP-A. In all three assays, intra- and inter-assay CVs were below $10 \%$ and $15 \%$ respectively. Detection limits were $0.5 \mu \mathrm{g} / \mathrm{L}$ for IGFBP-4, $0.4 \mu \mathrm{g} / \mathrm{L}$ for CT-IGFBP-4 and $0.9 \mu \mathrm{g} / \mathrm{L}$ for NT-IGFBP-4. As the assays for intact and PAPP-Afragmented IGFBP-4 are relatively new, these assays were the last to be performed. Hence, as some media vials were used, we were only able to measure intact and degraded IGFBP-4 in a limited number of samples.

\section{PAPP-A assay}

Media levels of PAPP-A were determined using a commercial ELISA, generously provided by Ansh Labs (Webster, TX, USA). The assay was performed according to protocol procedures. All samples were determined in single determination. 


\section{Real-time RT-PCR}

This was performed as outlined previously (30). Total RNA was extracted from frozen adipose tissue using TRIzol reagents (Gibco BRL, Life Technologies). The RNA concentration was determined by absorbance at $260 \mathrm{~nm}$, and purity and quality were checked by $260 / 280$ ratio and by gel electrophoresis respectively. Reverse transcription polymerase chain reaction (RT-PCR) was performed with random hexamer primers as described by the GeneAmp PCR Kit (Perkin Elmer Cetus). Realtime PCR was performed with a SYBR Green real-time PCR assay using an iCycler PCR machine from Bio-Rad Laboratories. The primers for target genes are shown in Table 1. Quantitative results obtained by real-time RT-PCR were expressed as cycle threshold (CT). The relative gene expression of target gene to $\beta$-actin was calculated by the formula $1 /\left((C \mathrm{~T} \text { target }-C \mathrm{~T} \beta \text {-actin })^{2}\right)$ as described previously (30).

\section{Statistics}

The vast majority of data did not comply with a parametric distribution, and log transformation did not change this. Therefore, we used Mann-Whitney rank sum test, Wilcoxon signed rank sum test or Friedman repeatedmeasures analysis of variance on ranks as appropriate. A significant Friedman test was followed by the StudentNewman-Keul post hoc test, which is suitable for multiple comparisons. The only exception was IGFBP-4 data from obese subjects (when comparing SAT and VAT before and after GH stimulation), which complied with a normal distribution. In this case we used repeated-measures ANOVA followed by Student-Newman-Keul post hoc test. Spearmen rank order correlation was used to study the associations between variables. $P$-values $<0.05$ were considered significant. All data are stated as median and interquartile range.

\section{Results}

\section{Protein levels in culture media}

\section{GH stimulation of SAT from lean women}

SAT from lean women were available in large amounts and therefore used to study the effect of increasing doses of GH, comparing baseline (zero) vs 1, 10 and $100 \mu \mathrm{g} / \mathrm{L}$. $\mathrm{GH}$ stimulation of SAT dose-dependently increased concentrations of IGF-I $(P=0.003$; Fig. 1A), IGF-II $(P=0.003$; Fig. $1 \mathrm{~B})$ and bioactive IGF $(P=0.003$; Fig. $1 \mathrm{C})$. IGFBP-4 also increased following GH stimulation $(P=0.002$; Fig. 1D), whereas its effects on PAPP-A were less clear-cut, as we only observed a difference when comparing GH concentrations of 1 and $100 \mu \mathrm{g} / \mathrm{L}$ $(P=0.02$; Fig. $1 \mathrm{E})$.

\section{SAT media from lean vs obese women}

SAT media from lean women were compared with SAT media from obese women, focusing on the conditions at baseline and after GH stimulation $(100 \mu \mathrm{g} / \mathrm{L})$. The most notable differences included IGFBP-4 (Fig. 1D) and PAPP-A (Fig. 1E), which at baseline were 2.0-fold and 1.8-fold higher, respectively, in SAT media from obese than those from lean women $(P<0.001)$. Upon $\mathrm{GH}$ treatment, the difference in IGFBP-4 persisted (Fig. 1D), whereas media levels of PAPP-A remained numerically, but insignificantly, higher in obese SAT media (Fig. 1E).

GH stimulation increased media concentrations of IGF-I $(P<0.05$; Fig. $1 \mathrm{~A})$ similarly in SAT from lean and obese women. By contrast, IGF-II decreased $(P<0.05)$ in obese SAT media, but increased $(P<0.05)$ in lean SAT media (Fig. 1B). The opposing responses of IGF-II to GH stimulation may explain that bioactive IGF increased less in obese than in lean SAT media $(P<0.05$; Fig. $1 C)$. A few other differences in the response to $\mathrm{GH}$ stimulation were noticed. GH stimulation caused a small, but significant

Table 1 Primers used in the study.

\begin{tabular}{ll}
\hline Target & Sense \\
\cline { 1 - 1 } IGF-I & GACAGGGGCTTTTATTTCAAC \\
IGF-II & AGCCGTGGCATCGTTGAG \\
PAPP-A & CAGTCAGCTGCTCAACGGAA \\
GH receptor & ATTTTCTAAACAGCAAAGGA \\
IGF-I receptor & AAAAGGAATGAAGTCTGGCTC \\
IGF-II receptor & CCCGGAGCACTACCTCA \\
IGFBP-4 & GCCACTTGCGCCCTGGGCTT \\
\hline
\end{tabular}

\begin{tabular}{lcc}
\hline Antisense & & Product size (base pairs) \\
\hline CTCCAGCCTCCTTAGATCAC & 117 \\
GGTCTTGGGTGGGTAGAGCAATC & 310 \\
GCAGGCTCTGGGACTGCAC & 194 \\
CACTGTGGAATTCGGGTTTA & 158 \\
CACAATGTAGTTATTGGACAC & 517 \\
ACATAAGTCGCCATCAACGTA & 187 \\
GTCAGCCAGCTGGTGGCAGTCCAGCTC & 594 \\
\hline
\end{tabular}

www.eje-online.org 
A

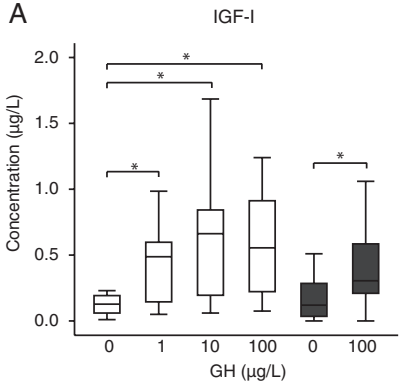

C

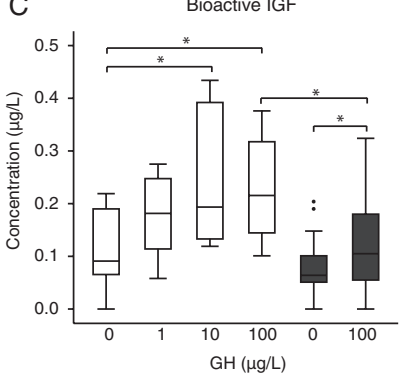

E

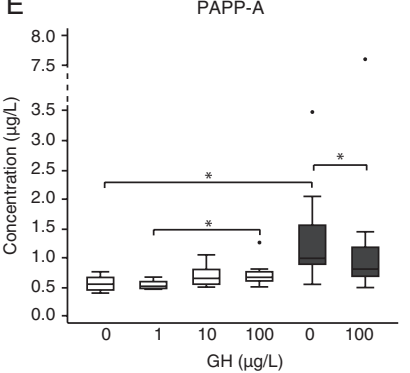

Figure 1

IGF-related peptides in culture medium from SAT obtained from lean and obese women. White boxes show media levels of IGF-related peptides from cultures of SAT obtained from eight lean women. Each SAT was incubated with increasing concentrations of GH (0 (baseline), 1, 10 and $100 \mu \mathrm{g} / \mathrm{L}$ ) added to the incubation medium. Dark gray boxes show media levels in cultures from 17 obese women treated with 0 (baseline) and $100 \mu \mathrm{g} / \mathrm{L} \mathrm{GH}$. The two tissue donor groups were matched according to age. All data are stated as median (interquartile range). Among lean women, the effect of SAT stimulation with increasing concentrations of $\mathrm{GH}$ was tested using the Friedman repeated-measures analysis of variance on ranks, which if significant was followed by the Student-NewmanKeul test. Differences between SAT from lean and obese women were found using the Mann-Whitney test, and differences within obese women were found using the Wilcoxon test. ${ }^{*} P<0.05$. increase in IGFBP-4 levels in SAT media from lean but not obese women $(P<0.05$; Fig. 1D), whereas GH stimulation decreased PAPP-A levels in SAT media from obese but not lean women $(P<0.05$; Fig. 1E).

\section{VAT media vs SAT media from obese subjects}

The paired experiment compared SAT and VAT media before and after GH stimulation $(100 \mu \mathrm{g} / \mathrm{L})$. As we did not observe clear gender differences (data not shown), it was decided to pool data. At baseline, IGF-I concentrations (Fig. 2A) did not differ between unstimulated VAT and SAT media, whereas bioactive IGF levels were 1.8-fold higher in VAT than those in SAT media $(P<0.005)$. Stimulation by GH increased IGF-I concentrations (Fig. 2A) and bioactive IGF (Fig. 2C) in both media $(P<0.05)$, with both levels being higher in VAT than those in SAT $(P<0.05)$. In contrast to IGF-I, GH altered neither IGF-II concentrations in SAT nor VAT media. Noteworthy, VAT media contained significantly higher IGF-II concentrations than SAT media at baseline (1.4-fold) as well as after GH stimulation (2.1fold) $(P<0.005)$ (Fig. 2B). This observation may explain that VAT media contained significantly higher levels of bioactive IGF (Fig. 2C) than SAT media at baseline $(P<0.05)$ as well as after $\mathrm{GH}$ stimulation $(P<0.05)$.

Another marked difference between SAT and VAT was their secretion of IGFBP-4 and PAPP-A. When measured with the commercial IGFBP-4 assay, VAT media contained approximately twice as much IGFBP-4 (Fig. 2D) and four times as much PAPP-A $(P<0.001)$ as SAT at baseline, and this difference remained unchanged after GH stimulation (Fig. 2E). GH did not change PAPP-A levels in media from VAT, but caused a small yet significant reduction in PAPP-A levels from SAT.

IGFBP-4 normally inhibits IGF-mediated IGF-IR activation in vitro. Hence, the combination of high levels of IGFBP-4 and bioactive IGF in VAT media was counterintuitive compared with SAT media. However, we learned that the commercial IGFBP-4 assay detected both intact IGFBP-4 and NT-IGFBP-4 generated upon PAPP-A cleavage (data not shown). Accordingly, baseline media IGFBP-4 levels were re-measured using our IGFBP-4 fragment-specific assays (29). By these assays we could demonstrate that intact IGFBP-4 levels were identical in VAT and SAT media, whereas levels of NT and CT fragments were 1.5-fold and 3.3-fold respectively higher in VAT than in SAT $(P<0.01$; Fig. 3A). Based on these findings, we returned to SAT media from lean women. We had only access to media from SAT exposed to $1.0 \mu \mathrm{g} / \mathrm{L}$ $\mathrm{GH}$, but still these measurements (Fig. 3B) showed similar 
A

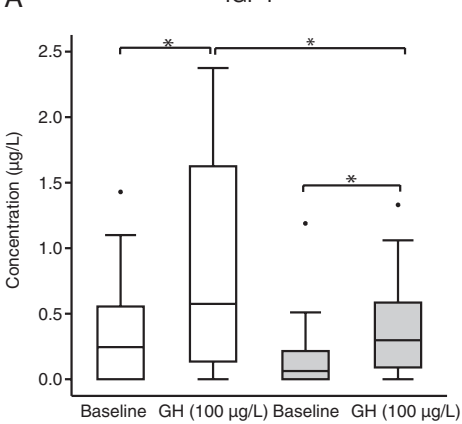

D

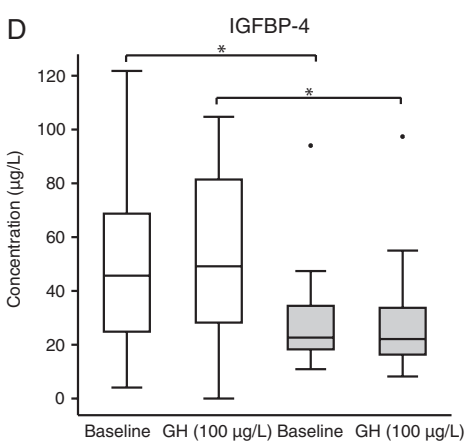

B

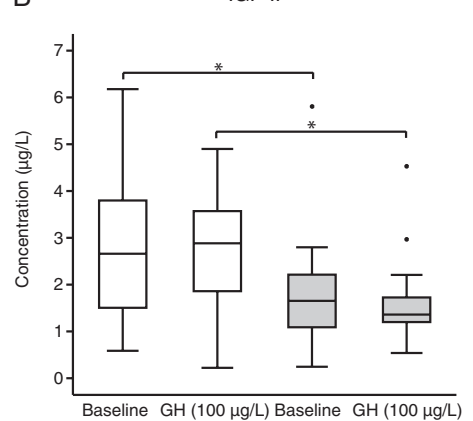

E

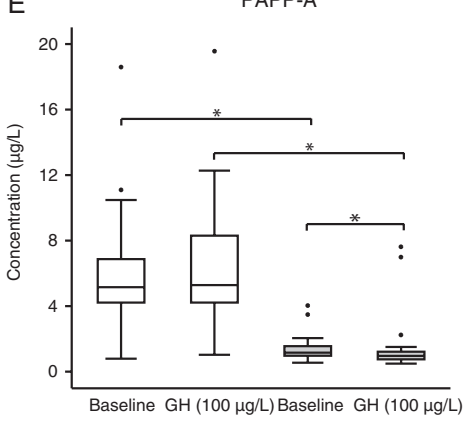

C Bioactive IGF

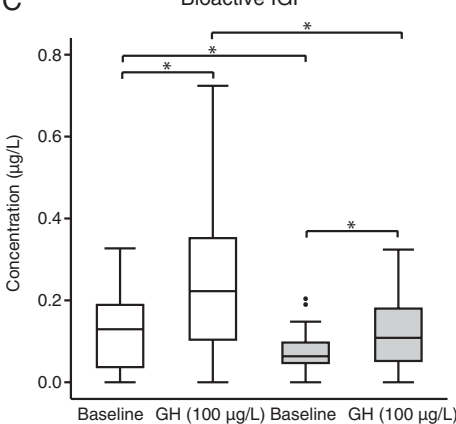

$\square$ Visceral adipose tissue

$\square$ Subcutaneos adipose tissue

\section{Figure 2}

Culture media levels of IGF-related peptides from SAT and VAT from obese subjects. White and gray boxes show media levels of IGF-related peptides from cultures of VAT and SAT respectively. Data are based on paired observations of VAT and SAT from 26 obese subjects. All data are stated as median (interquartile range). Differences between protein levels were analyzed using the Friedman repeated-measures analysis of variance (ANOVA) on ranks, which if significant was followed by the Student-Newman-Keul method. The only exception was IGFBP-4 levels, which complied with the normal distribution and therefore were compared by repeated-measures ANOVA, and subsequently the Student-Newman-Keul test. ${ }^{\star} P<0.05$.

levels of intact as well as NT- and CT-IGFBP-4, i.e. as observed in SAT media from obese women (Fig. 3A).

Correlations between levels of bioactive IGF, IGFBP-4 and PAPP-A are shown in Table 2. The three distinct measures of IGFBP-4 were positively correlated in both SAT and VAT media. In VAT, bioactive IGF correlated positively with PAPP-A, and inversely with NT-IGFBP-4. No such correlations were observed in SAT.

\section{Correlations between BMI and GH induced increments in bioactive IGF and IGF-I}

To study the impact of BMI on the GH responsiveness of SAT, data from lean and obese women were analyzed using Spearman rank order correlations between BMI and increments in bioactive IGF and IGF-I concentrations, following $\mathrm{GH}$ stimulation (i.e. concentrations after $\mathrm{GH}$ stimulation minus concentrations at baseline). BMI correlated inversely with the increase in bioactive IGF $(r=-0.54 ; P=0.005 ; n=25)$, but not with the increase in IGF-I concentration $(r=-0.16 ; P=\mathrm{NS} ; n=25)$.

\section{mRNA levels in adipose tissue cultures}

\section{GH stimulation of SAT from lean women}

Upon GH treatment, the expression of IGF-I increased, but only at the highest GH dose $(P<0.05$; Table 3$)$. Otherwise, no significant effects of $\mathrm{GH}$ were detected.

\section{SAT from lean vs obese women}

SAT from obese women contained higher baseline expression of IGF-IR, IGF-IIR, IGF-II and IGFBP-4 and lower expression of GHR and PAPP-A, compared with SAT from lean women, whereas the expression of IGF-I was similar (all $P<0.05$; Table 3 ). The differences in expression patterns were slightly altered following $\mathrm{GH}$ stimulation, as GHR and IGF-II were no longer different 
A

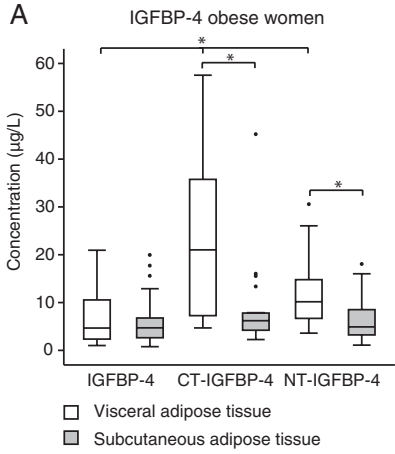

Figure 3

Culture media levels of intact IGFBP-4 and IGFBP-4 fragments. Intact IGFBP-4 and IGFBP-4 fragments were measured in culture media from VAT and SAT from obese women (A) and SAT from lean women (B). The two fragments were determined by assays that are specific for the PAPP-A-generated neo-epitopes on the IGFBP-4 fragments. As we had only limited media available for the assays, measurements on obese women $(A)$ were restricted to the baseline condition only. In lean women (B), measurements were performed on SAT media following stimulation with the lowest $\mathrm{GH}$ dose $(1 \mu \mathrm{g} / \mathrm{L})$. No difference between the concentrations of intact IGFBP-4 and the two IGFBP-4 fragments was observed. All data are stated as median (interquartile range). Differences between protein levels were performed using the Friedman repeated-measures analysis of variance on ranks, which if significant was followed by the Student-Newman-Keul method. ${ }^{*} P<0.05$.

between SAT from obese and lean women, whereas the other differences observed at baseline persisted $(P<0.05$; Table 3). Finally, SAT from lean and obese women responded similarly to GH as only the expression of IGF-I increased $(P<0.05)$.

\section{VAT vs SAT from obese subjects}

At baseline, SAT showed a higher expression of GHR and a lower expression of PAPP-A than VAT $(P<0.05$; Table 4), but apart from this no differences were observed. GH stimulation increased IGF-I expression similarly in SAT and VAT, whereas the expression of GHR was no longer different between the two tissues. Otherwise, GH stimulation caused no changes in the expression pattern observed at baseline.

\section{Discussion}

This study compared the expression, secretion and GH responsiveness of proteins belonging to the IGF system in cultures of VAT and SAT from lean and obese subjects. A central observation was that adipose tissue cultures secrete substantial amounts of enzymatically active PAPP-A, IGFBP-4 and IGF-II in a depot-specific manner. Thus, VAT media contained substantially more IGF-II, PAPP-A and PAPP-A-degraded IGFBP-4 fragments than SAT media. Consequently, VAT media possessed an increased IGF-IR activation potential in vitro. Another central observation was that in obese subjects, GH stimulation resulted in a higher secretion of IGF-I from VAT than SAT, whereas SAT from obese and lean women responded with similar increases in IGF-I following GH stimulation.

SAT from obese women secreted almost twice as much PAPP-A as SAT from lean women. Furthermore, VAT from obese subjects secreted more than four times as much PAPP-A as SAT, which confirm in a human setting what has previously been documented pre-clinically (17). In addition, IGFBP-4 was highly abundant in culture media. However, using highly specific IGFBP-4 fragment assays

Table 2 Spearmen rank order correlation between media levels of bioactive IGF, intact IGFBP-4, N-terminal IGFBP-4, C-terminal IGFBP-4 and PAPP-A. All correlations are based on 26 VAT and SAT media, analyzed separately. Only data from unstimulated tissues (baseline condition) are available. Data are stated as $r$-values and $P$-values. For clarity, only data with correlations with $P$-values below 0.05 have been included.

\begin{tabular}{|c|c|c|c|c|c|}
\hline \multirow[b]{2}{*}{ SAT } & \multicolumn{5}{|c|}{ VAT } \\
\hline & IGF bioactivity & Intact IGFBP-4 & $\mathrm{N}$-terminal IGFBP-4 & C-terminal IGFBP-4 & PAPP-A \\
\hline IGF bioactivity & & NS & $-0.50 ; P<0.009$ & NS & $0.45 ; P<0.03$ \\
\hline Intact IGFBP-4 & NS & & $0.53 ; P<0.006$ & $0.80 ; P<0.0001$ & NS \\
\hline $\begin{array}{l}\text { N-terminal } \\
\text { IGFBP-4 }\end{array}$ & NS & $0.50 ; P<0.01$ & & $0.43 ; P<0.03$ & NS \\
\hline $\begin{array}{l}\text { C-terminal } \\
\text { IGFBP-4 }\end{array}$ & NS & $0.84 ; P<0.0001$ & $0.53 ; P<0.006$ & & NS \\
\hline PAPP-A & NS & NS & NS & NS & \\
\hline
\end{tabular}

All significant correlations are in bold. NS, not significant. 

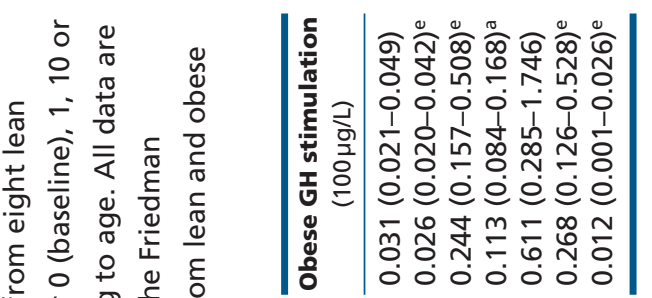

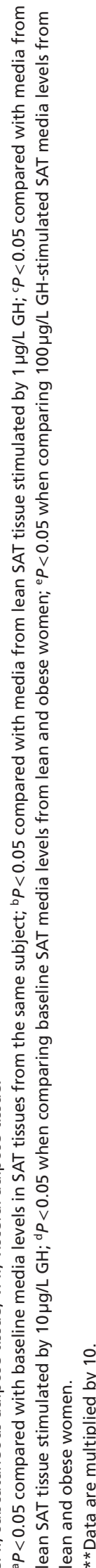

(29) we could demonstrate that the apparently higher concentration of IGFBP-4 in VAT media was in fact due to elevated levels of PAPP-A-generated CT- and NT-IGFBP-4 fragments rather than intact IGFBP-4. Furthermore, the apparent difference in IGFBP-4 immunoreactivity between SAT media from obese and lean women vanished when using specific IGFBP-4 assays. In our opinion these findings highlight that the interpretation of IGFBP data may be grossly biased unless the presence of IGFBPfragments is taken into account.

The primary function of PAPP-A is to cleave IGFBP-4 in an IGF-dependent manner, and thereby to release bound IGF for receptor activation $(11,12)$. Accordingly, it is tempting to speculate that the increased ability of VAT media to activate the IGF-IR in vitro (i.e. bioactive IGF) is secondary to an upregulated PAPP-A-mediated release of IGFBP-4-complexed IGF. This view is supported by the positive relationship between PAPP-A and bioactive IGF as demonstrated in VAT media. On the other hand, we would also have predicted positive correlations between bioactive IGF levels and the two IGFBP-4 fragments, which are generated by PAPP-A in a 1:1 molar ratio. However, media concentrations of the CT- and NT-fragments were significantly distinct, in particular in VAT. Accordingly, we speculate that the clearance of the two fragments, whether this involves cellular uptake and/or further enzymatic degradation in the incubation media, may be responsible for the lack of relationship between the two PAPP-A-generated IGFBP-4 fragment levels and bioactive IGF.

Our IGF bioassay cannot discriminate between IGF-Iand IGF-II-mediated IGF-IR activation. Given that IGF-II cross-reacts with the affinity being $12 \%$ of that of IGF-I (26) and that media IGF-II was considerably higher than IGF-I, locally produced IGF-II may contribute substantially to IGF-IR activation within adipose tissues. Noteworthy, obese subjects have higher serum IGF-II than lean subjects (31). Therefore, we hypothesize that a significant part of circulating IGF-II originates from adipose tissue.

It is remarkable that $200 \mathrm{mg}$ adipose tissue, incubated in $2 \mathrm{~mL}$ medium for $48 \mathrm{~h}$ is able to secrete PAPP-A in concentrations exceeding what is usually measured in the circulation $(29,32)$. Since obese subjects do not have elevated serum PAPP-A (33), our observation supports the notion that PAPP-A is primarily active within the tissues $(11,12)$. It was beyond the scope of this study to explore the mechanisms responsible for the excessive secretion of PAPP-A, but mRNA data indicate different possibilities. When comparing SAT from lean and obese subjects, the latter group presented a higher secretion 
Table 4 Adipose tissue mRNA densities of GH and IGF-related peptides and receptors in SAT and VAT. Each group consists of 26 mRNA measurements. Each study participant served as a donor of VAT and SAT. Thus, data are based on paired observations. All data are stated as median (interquartile range). Differences between mRNA levels were performed using the Friedman repeated-measures analysis of variance on ranks, which if significant was followed by the Student-Newman-Keul method.

\begin{tabular}{l}
\hline mRNA \\
\hline GHR* \\
IGF-IR \\
IGF-IIR \\
IGF-I \\
IGF-II \\
IGFBP-4 \\
PAPP-A** \\
\hline
\end{tabular}

\begin{tabular}{c}
\hline VAT baseline \\
\hline $0.014(0.001-0.045)$ \\
$0.031(0.024-0.084)$ \\
$0.264(0.107-0.668)$ \\
$0.051(0.025-0.114)$ \\
$1.122(0.423-3.242)$ \\
$0.300(0.150-0.925)$ \\
$0.032(0.010-0.071)$ \\
\hline
\end{tabular}

\begin{tabular}{c}
\hline VAT GH stimulation $(100 \mu \mathrm{g} / \mathrm{L})$ \\
\hline $0.014(0.011-0.053)$ \\
$0.030(0.025-0.079)$ \\
$0.256(0.138-1.026)$ \\
$0.106(0.036-0.283)^{a}$ \\
$0.933(0.399-5.596)$ \\
$0.289(0.194-1.292)$ \\
$0.021(0.011-0.244)$ \\
\hline
\end{tabular}

\begin{tabular}{c} 
SAT baseline \\
\hline $0.036(0.020-0.087) *$ \\
$0.028(0.021-0.050)$ \\
$0.311(0.158-0.786)$ \\
$0.031(0.019-0.100)$ \\
$0.683(0.420-2.769)$ \\
$0.358(0.180-0.724)$ \\
$0.007(0.004-0.039)^{\mathrm{b}}$ \\
\hline
\end{tabular}

\begin{tabular}{c} 
SAT GH stimulation $(100 \mu \mathrm{g} / \mathrm{L})$ \\
\hline $0.031(0.018-0.050)$ \\
$0.027(0.017-0.046)$ \\
$0.313(0.190-0.557)$ \\
$0.108(0.083-0.174)^{\mathrm{a}}$ \\
$0.647(0.341-1.810)$ \\
$0.289(0.126-0.551)$ \\
$0.013(0.006-0.031)^{\mathrm{c}}$
\end{tabular}

$\mathrm{R}$, receptor; SAT, subcutaneous adipose tissue; VAT, visceral adipose tissue.

${ }^{a} P<0.05$ when comparing baseline and GH-stimulated tissue of similar localization; ${ }^{b} P<0.05$ when comparing baseline SAT and VAT; ${ }^{c} P<0.05$ when comparing GH-stimulated SAT and VAT.

*Friedman's test was significant, but the post hoc test could not identify differences between groups. However, a paired test (Wilcoxon) showed that levels of GHR was significantly higher in SAT than those in VAT at baseline $(P<0.02)$, but not after GH stimulation $(P=$ NS); **Data are multiplied by 10 .

of PAPP-A protein, despite a lower mRNA expression. In obese subjects, on the other hand, the mRNA expression followed the secretion, being high in VAT and low in SAT. In summary, this indicates that transcriptional as well as post-translational mechanisms may be in play.

In this study we focused on IGFBP-4, but adipose tissue is indeed reported to express all IGFBPs (2). We were able to detect the mRNA expression of IGFBP-2, $-3,-5$ and -6 (data not shown), but the incubation media contained no detectable IGFBP-2 or -3 protein, as previously reported by us (3), and we had no assay for IGFBP-5. Therefore these data were not included. The only other IGFBP present in the incubation media in detectable concentrations was IGFBP-6 (data not shown). Similar to IGFBP-4, levels of IGFBP-6 were higher in VAT media than SAT media (median levels being $\approx 12$ and $\approx 6 \mu \mathrm{g} / \mathrm{L}$ respectively), with no difference between SAT from lean and obese women. Thus, IGFBP- 6 may also play a role in adipose tissue and indeed this tissue may be used as a model to improve our incomplete understanding of the role of IGFBP-6 in human biology.

Both VAT and SAT responded to GH stimulation by increasing IGF-I production, but VAT appeared to be more GH sensitive than SAT. This is in line with clinical studies showing that treatment of GH-deficient patients results in a relatively more pronounced reduction in VAT than that in SAT $(34,35,36)$. On the other hand, neither the expression of IGF-IR nor the expression of IGF-I differed between the two fat depots; if anything, the expression of GHR was lower in VAT than that in SAT. Thus, the ability of VAT to secrete more IGF-I than SAT may be caused by post-transcriptional mechanisms. In this context it is tempting to focus on insulin, which shares overlapping intercellular signaling cascades with GH (37). However, our tissue culture system requires insulin to be added to the incubation medium; therefore, it is not possible to study the distinct effects of $\mathrm{GH}$ in the absence of insulin.

The liver is the major source of circulating IGF-I (28) and obese subjects respond with larger increases in IGF-I following GH stimulation than lean subjects (25), indicative of an augmented hepatic GH sensitivity (24). On this basis, we found it of interest to study whether the increased $\mathrm{GH}$ responsiveness in obesity also included adipose tissue. However, data suggested the opposite as the baseline expression of GHR was lower in SAT from obese than that from lean women. Nevertheless, the two tissues responded with similar increases in IGF-I mRNA expression and protein secretion following GH stimulation, whereas the levels of bioactive IGF correlated inversely with BMI. Thus, obesity does not appear to increase the SAT synthesis of IGF-I following GH stimulation; indeed, the overall IGF bioactivity may be lower following GH exposure.

Our study has limitations. We compared whole tissue fragments and accordingly, differences in cellular composition and number of adipocytes in VAT and SAT were not taken into consideration $(14,36)$. We acknowledge that visceral adipocytes are in general smaller than subcutaneous adipocytes, and that the observed differences in $\mathrm{GH}$ response may in part relate to adipocyte numbers. However, from a biological point of view, we and others believe that studies of whole tissue fragments (including all cell types and extracellular matrix) are more representative of the physiology of adipose tissue in vivo than the studies of isolated adipocytes (36). It is also a limitation that we for practical reasons had to compare $200 \mathrm{mg}$ of SAT and VAT from obese women vs $500 \mathrm{mg}$ of 
SAT from lean women, as a comparison of similar tissue sizes would have been ideal. Further, depending on where the liposuction was performed, the lean SAT originated from hips as well as abdomen; although we do not believe so, this may have influenced our results. In addition, our study did not include details about diseases among the obese tissue donors. Drug lists from the participants revealed that some of the obese donors received antidiabetic medication and no doubt, it would be of interest to investigate the consequences of diabetes and its treatment on the IGF system in adipose tissue. Finally, as our data are obtained in vitro, one has to be cautious when extending these findings to the in vivo situation.

In this study we present novel data on the production of IGF components in human cultures of VAT and SAT. Given the demonstrated pro-atherogenic role of PAPP-A (11, 12, 38), our findings are compatible with the notion that VAT via a dysfunctional IGF system may be pathogenically linked to the development of cardiovascular disease, which is frequent in subjects suffering from visceral obesity (39).

\section{Declaration of interest}

The authors declare that there is no conflict of interest that could be perceived as prejudicing the impartiality of the research reported.

\section{Funding}

This work was supported by the Danish Medical Research Council and the Department of Clinical Medicine at Aarhus University, Denmark. R H was funded by a research grant from the Danish Diabetes Academy supported by the Novo Nordisk Foundation.

\section{Acknowledgements}

The authors thankfully acknowledge the technicians at the Medical Research Laboratory for technical assistance. The authors are grateful to HyTest Ltd. for providing antigens and antibodies for the IGFBP-4 and the two IGFBP-4 fragment assays. The authors also would like to thank Ansh Labs for providing kits for PAPP-A.

\section{References}

1 Wabitsch M, Heinze E, Debatin KM \& Blum WF. IGF-I- and IGFBP-3-expression in cultured human preadipocytes and adipocytes. Hormone and Metabolic Research 200032 555-559. (doi:10.1055/s-2007-978685)

2 Baxter RC \& Twigg SM. Actions of IGF binding proteins and related proteins in adipose tissue. Trends in Endocrinology and Metabolism 2009 20 499-505. (doi:10.1016/j.tem.2009.07.002)

3 Gude MF, Frystyk J, Flyvbjerg A, Bruun JM, Richelsen B \& Pedersen SB. The production and regulation of IGF and IGFBPs in human adipose tissue cultures. Growth Hormone and IGF Research 201222 200-205. (doi:10.1016/j.ghir.2012.09.004)

4 Scavo LM, Karas M, Murray M \& LeRoith D. Insulin-like growth factor-I stimulates both cell growth and lipogenesis during differentiation of human mesenchymal stem cells into adipocytes.
Journal of Clinical Endocrinology and Metabolism 200489 3543-3553. (doi:10.1210/jc.2003-031682)

5 Boney CM, Moats-Staats BM, Stiles AD \& D'Ercole AJ. Expression of insulin-like growth factor-I (IGF-I) and IGF-binding proteins during adipogenesis. Endocrinology 1994135 1863-1868. (doi:10.1210/ en.135.5.1863)

6 Smith PJ, Wise LS, Berkowitz R, Wan C \& Rubin CS. Insulin-like growth factor-I is an essential regulator of the differentiation of 3T3-L1 adipocytes. Journal of Biological Chemistry 1988263 9402-9408.

7 Chan SS, Twigg SM, Firth SM \& Baxter RC. Insulin-like growth factor binding protein-3 leads to insulin resistance in adipocytes. Journal of Clinical Endocrinology and Metabolism 200590 6588-6595. (doi:10.1210/jc.2005-0595)

8 Fischer-Posovszky P, Tornqvist H, Debatin KM \& Wabitsch M. Inhibition of death-receptor mediated apoptosis in human adipocytes by the insulin-like growth factor I (IGF-I)/IGF-I receptor autocrine circuit. Endocrinology 2004145 1849-1859. (doi:10.1210/ en.2003-0985)

9 Frystyk J. Free insulin-like growth factors - measurements and relationships to growth hormone secretion and glucose homeostasis. Growth Hormone and IGF Research 200414 337-375. (doi:10.1016/ j.ghir.2004.06.001)

10 Conover CA, Harstad SL, Tchkonia T \& Kirkland JL. Preferential impact of pregnancy-associated plasma protein-A deficiency on visceral fat in mice on high-fat diet. American Journal of Physiology: Endocrinology and Metabolism 2013305 E1145-1153. (doi:10.1152/ ajpendo.00405.2013)

11 Conover CA. Key questions and answers about pregnancy-associated plasma protein-A. Trends in Endocrinology and Metabolism 201223 242-249. (doi:10.1016/j.tem.2012.02.008)

12 Oxvig C. The role of PAPP-A in the IGF system: location, location, location. Journal of Cell Communication and Signaling 20159 177-187. (doi:10.1007/s12079-015-0259-9)

13 Motoshima H, Wu X, Sinha MK, Hardy VE, Rosato EL, Barbot DJ, Rosato FE \& Goldstein BJ. Differential regulation of adiponectin secretion from cultured human omental and subcutaneous adipocytes: effects of insulin and rosiglitazone. Journal of Clinical Endocrinology and Metabolism 200287 5662-5667. (doi:10.1210/ jc.2002-020635)

14 Ibrahim MM. Subcutaneous and visceral adipose tissue: structural and functional differences. Obesity Reviews 201011 11-18. (doi:10.1111/ j.1467-789X.2009.00623.x)

15 Fox CS, Massaro JM, Hoffmann U, Pou KM, Maurovich-Horvat P, Liu CY, Vasan RS, Murabito JM, Meigs JB, Cupples LA et al. Abdominal visceral and subcutaneous adipose tissue compartments: association with metabolic risk factors in the Framingham Heart Study. Circulation 2007116 39-48. (doi:10.1161/CIRCULATIONAHA.106.675355)

16 Davidge-Pitts C, Escande CJ \& Conover CA. Preferential expression of PAPPA in human preadipocytes from omental fat. Journal of Endocrinology 2014222 87-97. (doi:10.1530/JOE-13-0610)

17 Tchoukalova YD, Nathanielsz PW, Conover CA, Smith SR \& Ravussin E. Regional variation in adipogenesis and IGF regulatory proteins in the fetal baboon. Biochemical and Biophysical Research Communications 2009380 679-683. (doi:10.1016/j.bbrc.2009.01.149)

18 Tchkonia T, Lenburg M, Thomou T, Giorgadze N, Frampton G, Pirtskhalava T, Cartwright A, Cartwright M, Flanagan J, Karagiannides I et al. Identification of depot-specific human fat cell progenitors through distinct expression profiles and developmental gene patterns. American Journal of Physiology: Endocrinology and Metabolism 2007292 E298-307. (doi:10.1152/ajpendo.00202.2006)

19 Leung KC, Doyle N, Ballesteros M, Waters MJ \& Ho KK. Insulin regulation of human hepatic growth hormone receptors: divergent effects on biosynthesis and surface translocation. Journal of Clinical Endocrinol and Metabolism 200085 4712-4720. (doi:10.1210/ jc.85.12.4712) 
20 Rasmussen MH. Obesity, growth hormone and weight loss. Molecular and Cellular Endocrinology 2010316 147-153. (doi:10.1016/j. mce.2009.08.017)

21 Stanley TL \& Grinspoon SK. Effects of growth hormone-releasing hormone on visceral fat, metabolic, and cardiovascular indices in human studies. Growth Hormone and IGF Research 201525 59-65. (doi:10.1016/j.ghir.2014.12.005)

22 Frystyk J, Brick DJ, Gerweck AV, Utz AL \& Miller KK. Bioactive insulinlike growth factor-I in obesity. Journal of Clinical Endocrinology and Metabolism 200994 3093-3097. (doi:10.1210/jc.2009-0614)

23 Friedrich N, Jørgensen T, Juul A, Spielhagen C, Nauck M, Wallaschofski H \& Linneberg A. Insulin-like growth factor I and anthropometric parameters in a Danish population. Experimental and Clinical Endocrinology and Diabetes 2012120 171-174. (doi:10.105 5/s-0031-1301289)

24 Savastano S, Di Somma C, Barrea L \& Colao A. The complex relationship between obesity and the somatropic axis: the long and winding road. Growth Hormone and IGF Research 201424 221-226. (doi:10.1016/j.ghir.2014.09.002)

25 Gleeson HK, Lissett CA \& Shalet SM. Insulin-like growth factor-I response to a single bolus of growth hormone is increased in obesity. Journal of Clinical Endocrinol and Metabolism 200590 1061-1067. (doi:10.1210/jc.2004-0501)

26 Chen JW, Ledet T, Ørskov H, Jessen N, Lund S, Whittaker J, De Meyts P, Larsen MB, Christiansen JS \& Frystyk J. A highly sensitive and specific assay for determination of IGF-I bioactivity in human serum. American Journal of Physiology: Endocrinology and Metabolism 2003284 E1149-E1155. (doi:10.1152/ajpendo.00410.2002)

27 Reinhard M, Frystyk J, Jespersen B, Bjerre M, Christiansen J, Flyvbjerg A \& Ivarsen P. Effect of hyperinsulinemia during hemodialysis on the insulin-like growth factor system and inflammatory biomarkers: a randomized open-label crossover study. BMC Nephrology 201314 80. (doi:10.1186/1471-2369-14-80)

28 Espelund U, Grønbæk H, Villadsen GE, Simonsen K, Vestergaard PF, Jørgensen JO, Flyvbjerg A, Vilstrup H \& Frystyk J. The circulating IGF system in hepatocellular carcinoma: the impact of liver status and treatment. Growth Hormone and IGF Research 201525 174-181. (doi:10.1016/j.ghir.2015.05.002)

29 Hjortebjerg R, Lindberg S, Hoffmann S, Jensen JS, Oxvig C, Bjerre M \& Frystyk J. PAPP-A and IGFBP-4 fragment levels in patients with ST-elevation myocardial infarction treated with heparin and PCI. Clinical Biochemistry 201548 322-328. (doi:10.1016/j.clinbiochem.2014.11.022)

30 Bruun JM, Pedersen SB \& Richelsen B. Interleukin-8 production in human adipose tissue: inhibitory effects of anti-diabetic compounds, the thiazolidinedione ciglitazone and the biguanide metformin. Hormone and Metabolic Research 200032 537-541. (doi:10.1055/s-2007-978682)

31 Frystyk J, Skjærbæk C, Vestbo E, Fisker S \& Ørskov H. Circulating levels of free insulin-like growth factors in obese subjects: the impact of type 2 diabetes. Diabetes/Metabolism Research and Reviews 199915 314-322. (doi:10.1002/(SICI)1520-7560(199909/10)15:5<314::AIDDMRR56>3.0.CO;2-E)

32 Terkelsen CJ, Oxvig C, Norgaard BL, Glerup S, Poulsen TS, Lassen JF, Møller HJ, Thuesen L, Falk E, Nielsen TT et al. Temporal course of pregnancy-associated plasma protein-A in angioplasty-treated ST-elevation myocardial infarction patients and potential significance of concomitant heparin administration. American Journal of Cardiology 2009103 29-35. (doi:10.1016/j. amjcard.2008.08.027)

33 Woelfle J, Roth CL, Wunsch R \& Reinehr T. Pregnancy-associated plasma protein A in obese children: relationship to markers and risk factors of atherosclerosis and members of the IGF system. European Journal of Endocrinology 2011165 613-622. (doi:10.1530/EJE-11-0423)

34 Bengtsson BA, Eden S, Lonn L, Kvist H, Stokland A, Lindstedt G, Bosaeus I, Tolli J, Sjostrom L \& Isaksson OG. Treatment of adults with growth hormone (GH) deficiency with recombinant human GH. Journal of Clinical Endocrinology and Metabolism 199376 309-317. (doi:10.1210/jc.76.2.309)

35 Johannsson G, Marin P, Lonn L, Ottosson M, Stenlof K, Bjorntorp P, Sjostrom L \& Bengtsson BA. Growth hormone treatment of abdominally obese men reduces abdominal fat mass, improves glucose and lipoprotein metabolism, and reduces diastolic blood pressure. Journal of Clinical Endocrinology and Metabolism 199782 727-734. (doi:10.1210/jc.82.3.727)

36 Berryman DE, List EO, Sackmann-Sala L, Lubbers E, Munn R \& Kopchick JJ. Growth hormone and adipose tissue: beyond the adipocyte. Growth Hormone and IGF Research 201121 113-123. (doi:10.1016/j.ghir.2011.03.002)

37 Olarescu NC \& Bollerslev J. The impact of adipose tissue on insulin resistance in acromegaly. Trends in Endocrinology and Metabolism 2016 27 226-237. (doi:10.1016/j.tem.2016.02.005)

38 Hjortebjerg R, Tarnow L, Jorsal A, Parving HH, Rossing P, Bjerre M \& Frystyk J. IGFBP-4 fragments as markers of cardiovascular mortality in type 1 diabetes patients with and without nephropathy. Journal of Clinical Endocrinology and Metabolism 2015100 3032-3040. (doi:10.1210/jc.2015-2196)

39 Yusuf S, Hawken S, Ôunpuu S, Bautista L, Franzosi MG, Commerford P, Lang CC, Rumboldt Z, Onen CL, Lisheng L et al. Obesity and the risk of myocardial infarction in 27000 participants from 52 countries: a case-control study. Lancet 2005366 1640-1649. (doi:10.1016/s0140-6736(05)67663-5)

Received 1 July 2016

Revised version received 16 August 2016

Accepted 1 September 2016 